\title{
Determinants of Micro and Small Enterprise Growth in Southern Ethiopia
}

\author{
Bogale Boshe \\ Ph.D. Scholar, Wolaita Sodo University, Department of Rural Development and Agricultural Extension, \\ Wolaita Sodo, SNNPRS, Ethiopia
}

\begin{abstract}
The contributions of micro and small enterprises to create employment opportunity and fostering gross domestic product have been empirically examined. However, the determinants of their growth are different and there are inconsistent findings from the existing research. Thus, the study was conducted to identify micro and small enterprise growth determinants in Southern Ethiopia. The study applied explanatory research design and enterprise managers were taken as a sampling unit. A multi-stage sampling technique was used and the data were collected through questionnaires. The collected data using questionnaire were analyzed using Multiple Linear Regression Model to identify the factors that determine the micro and small enterprise growth. Therefore, the result indicated that among significant independent variables, educational level, work experience, and enterprise age were statistically significant at less than $0.1 \%$ significance level. Likewise, social networking and training were statistically significant at less than $1 \%$ significance level. Similarly, working area, group collateral, household asset, and attitude were also statistically significant at less than a 5\% significance level. Furthermore, all significant variables have a positive relationship with enterprise growth.
\end{abstract}

Keywords: MSEs, Growth, Multiple Linear Regressions, Small

DOI: $10.7176 / \mathrm{JESD} / 12-9-04$

Publication date:May $31^{\text {st }} 2021$

\section{INTRODUCTION}

Micro and small scale businesses are one catalyst in the socio-economic development of any country. It contributes substantially to the GDP, export earnings, and employment opportunities. Micro and small scale enterprises (MSEs) have been broadly acknowledged as the catalyst for sustainable economic development. Apart from the fact that MSEs contribute to the increase in per capita income and output, they also create employment opportunities, inspire the development of indigenous entrepreneurship, improve regional economic balance through industrial dispersal and generally stimulate effective resource utilization that is considered to be critical in the area of engineering economic development (Oppong et al., 2014)

In most developing countries, like India, Bangladeshi, Brazil, MSEs constitute the vast majority of firms, generating a significant share of overall employment and output. However, MSEs in Ethiopia have not performed creditably well, and they have not yet played an expected significant role in economic growth. They equally have not influenced beginner training to accelerate employment and poverty alleviation to promote Ethiopian economic development. This condition has been of great concern to the government at different levels, citizens, operators, practitioners, and organized private sectors (MOTI, 2005). The MSE sector's performance in Ethiopia is low compared to similar sectors in African countries such as South Africa, Kenya, Uganda, and Tanzania (Zeleke, 2010).

Understand the determinants of MSE growth is necessary for any policy intervention (Tekle, 2017). However, the lack of consistent findings by the existing research in Ethiopia has encouraged the researcher to explore why some microenterprises are successful and why others not or why some microenterprises have performed better than others, or vice versa. There might be various factors causing the variation in the growth of the microenterprises. Therefore, this study seeks to identify micro and small enterprise growth determinants in Southern Ethiopia.

\section{Literature Review}

\subsection{Definition of micro and small enterprises}

The definitions of MSE differ with different institutions setup. There is no universally acceptable definition of MSEs. Different scholars define MSEs differently based on the level of development of the country under review. However, in Ethiopia, the central statistical authority defined MSE based on the size of employment and the extent of automation for small scale enterprises and used a combination of these criteria for defining such enterprises. Accordingly, "microenterprise" means an enterprise excluding building, not exceeding Birr 50,000 in the case of the service sector or not exceeding Birr 100,000 in the industrial sector, and engages five workers, including the owner, his family members, and other employees. The same regulation defines "small enterprise" as an enterprise Birr 50,001 to 500,000 in the case of the service sector or Birr 100,001 to Birr 1,500,000 in the case of the industrial sector and engages 6 to 30 workers including the owner, his family members, and other 
employees (CSA, 2013).

\subsection{Theories of growth of micro and small enterprise}

Various theoretical models have been developed which explain the growth of MSEs. One theoretical model class focuses on the learning process, either passive or active, and the other theory refers to the stochastic and deterministic approaches.

Passive Learning Model: In the Passive Learning Model (PLM), a firm enters a market without knowing its potential growth. Only after entry does the firm start to learn about the distribution of its profitability based on information from realized profits; by continually updating such learning, the firm decides to contract, expand, or exit. This learning model states that firms and managers of firms learn about their efficiency once established in the industry. Firms expand their activities when managers observe that their managerial efficiency estimation has understated actual levels of efficiency. As the firm age increases, the owner's estimation of efficiency becomes more accurate, decreasing the probability that the output will widely differ from one year to another. This theoretical model implies that the size and age of the firm determines enterprise growth (Stranova, 2001).

Stochastic and deterministic Approaches: The other set of growth theories of firms include the Stochastic and Deterministic Approaches. The stochastic model, which is also known as the Gibrat's Law, argues that all size changes are due to chance. Thus, the size and age of firms do not affect the growth of MSEs. According to Bacchetti and Trovato (undated), empirical of the law has indicated that it only considers size and age as potential variables that may significantly affect firm growth. The deterministic approach assumes, on the contrary, that differences in the rates of growth across firms affected by a set of observable industry and firmspecific characteristics (Giovanni et al., 2007).

\subsection{Measures of MSE growth}

According to USAID (2002), the standard measure of growth used in MSEs firms' studies is the number of workers since startup. This variable is relatively easy for respondents to remember and does not need many workers since startup. This variable is relatively easy for respondents to remember. On the other hand, MSE growth is measure using enterprise profit (Dunn \& Arbuckle, 2005). This study also used enterprise profit as a proxy variable for enterprise growth.

\subsection{Factors Influencing of Growth of Micro and Small Enterprises}

Numerous factors have persistently challenged the growth of MSEs. Accordingly, Audretsch and Klepper(2009) note that a small firm has a lower likelihood of survival, and at the same time, firm size is found to be negatively related to growth. Education is one factor that positively impacts firms' growth (King and McGrath, 2002). In terms of education or vocational training, those entrepreneurs with more massive human capital stocks are better placed to improve their enterprises to continually changing business environments (King and McGrath, 2008). Infrastructure, as it relates to provision of roads, electricity, water, sewerage, and telecommunication has been a significant constraint on the development of MSEs (Bokea et al., 2009).

Gender can be understood as the socio-cultural manifestation of the sex of a person. Studies have observed significant differences in the performance between female-owned and male-owned firms. Women-owned ventures were less likely to grow and more likely to exhibit lower business performance (Nganda et al., 2014). Similarly, Yitbarek (2016) found that women-owned enterprises are less likely to grow than men-owned.

\subsection{Conceptual Framework}

The conceptual framework of the study is represented in Figure 1. It indicates that micro and small enterprises' growth in terms of profit growth depends on some enterprise-related, entrepreneur-related, and socio-economic and institutional factors. 


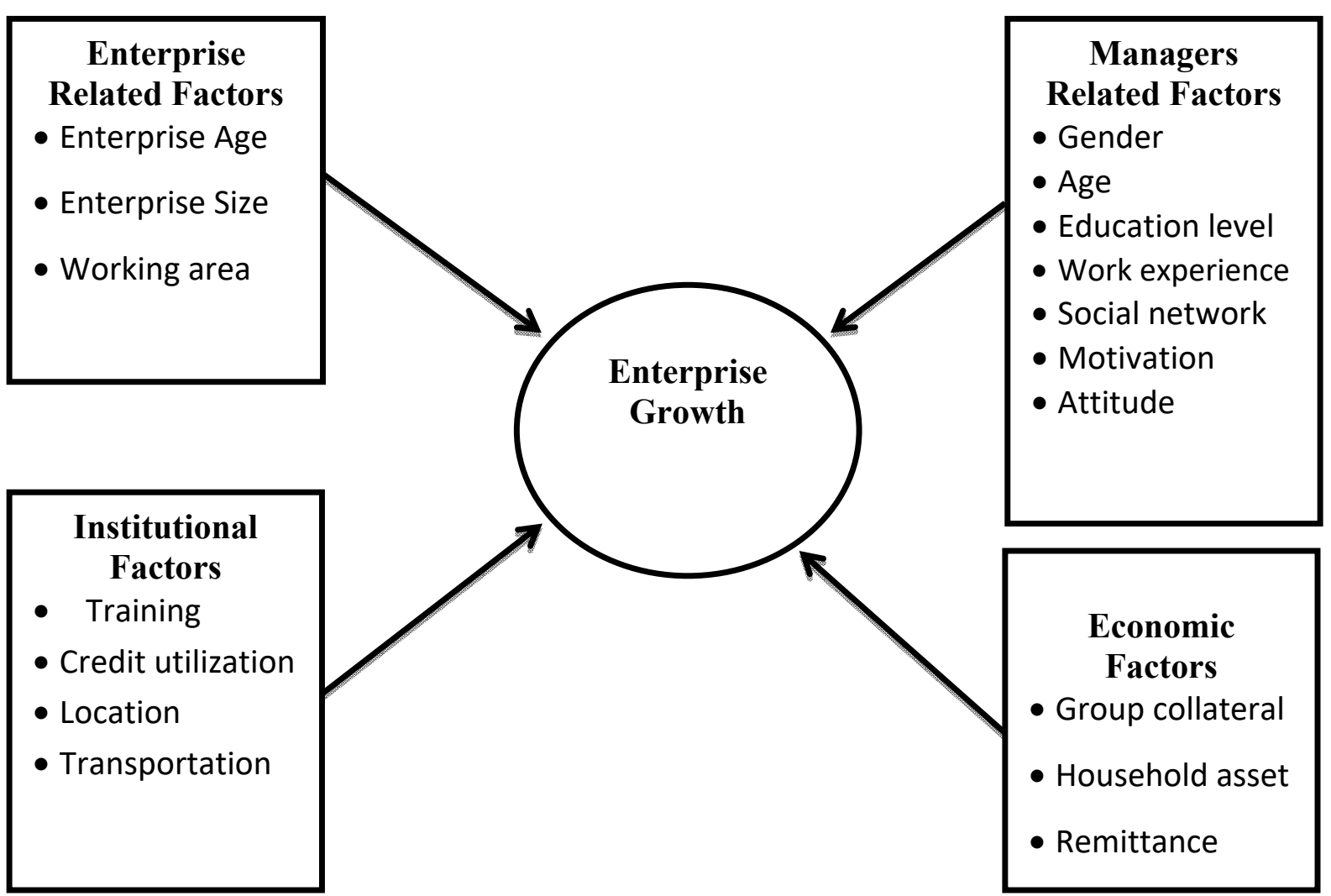

Figure 1: Conceptual framework of the study

Source: Own construction from the literature review (2020)

\section{Research Methodology}

Research design can be defined as the blueprint for fulfilling research objectives and answering research questions (John et al., 2007). In other words, it is a master plan specifying the methods and procedures for collecting and analyzing the needed information. It ensures that the study will be relevant to the problem and that it uses economic procedures. Exploratory research design emphasizes the discovery of ideas and insights. Descriptive research design is concerned with summarizing the frequency with which an event occurs or the relationship between variables, and explanatory research design concerned with determining the cause and effect relationships. Therefore, the types of research that were employed in this study is explanatory research. This is because the study aims at estimating the integrated influence of the factors on micro and small enterprise growth.

The study used primary data sources, and the main data sources were collected from micro and small enterprise managers. A multi-stage sampling technique was used to get the representative number of respondents. Three towns, namely Arbaminch from Gamo, Hosana from Hadiya, and Yirgalem from Sidama zones, were chosen for this study purposively. There are 3118 MSEs in the three towns (Arbaminch, Yirgalem, and Hosanna). As the population is finite, Yamane's (1967) sampling formula was selected. The required sample size at $95 \%$ confidence intervals would be determined as follows.

$$
\begin{aligned}
& n=\frac{N}{1+N(e)^{2}} \\
& n=\frac{3118}{1+3118(0.0025)} \\
& n \approx 355
\end{aligned}
$$

Next, a stratified random sampling technique was used to divide micro and small enterprises into four sectors: manufacturing, construction, trade, and service. Then, a proportional number of respondents were determined from each strata using PPS Sampling Method (see Table 1). Finally, systematic random sampling technique was adopted to select the ultimate respondents included in the study. 
Table 1: Sample design

\begin{tabular}{|c|c|c|c|c|c|c|c|c|c|c|c|c|}
\hline \multirow{3}{*}{ Town } & \multicolumn{6}{|c|}{ Micro-Enterprise } & \multicolumn{6}{|c|}{ Small Enterprise } \\
\hline & \multicolumn{3}{|c|}{ Population } & \multicolumn{3}{|c|}{ Sample } & \multicolumn{3}{|c|}{ Population } & \multicolumn{3}{|c|}{ Sample } \\
\hline & $\mathrm{M}$ & $\mathrm{F}$ & $\mathrm{T}$ & $\mathrm{M}$ & $\mathrm{F}$ & $\mathrm{T}$ & $\mathrm{M}$ & $\mathrm{F}$ & $\mathrm{T}$ & $\mathrm{M}$ & $\mathrm{F}$ & $\mathrm{T}$ \\
\hline Arbaminch & 670 & 450 & 1120 & 76 & 51 & 117 & 77 & 53 & 130 & 9 & 6 & 15 \\
\hline Hosana & 720 & 180 & 900 & 82 & 20 & 102 & 68 & 80 & 148 & 8 & 9 & 17 \\
\hline Yirgalem & 560 & 41 & 601 & 64 & 5 & 69 & 99 & 120 & 219 & 11 & 14 & 25 \\
\hline Total & 1950 & 671 & 2621 & 229 & 76 & 298 & 244 & 253 & 497 & 28 & 29 & 57 \\
\hline
\end{tabular}

Note: $\mathrm{M}=$ Male, $\mathrm{F}=$ Female, $\mathrm{T}=$ Total

The data were collected through a questionnaire defined as a standardized set of questions to obtain information from a sample of the target population. Even though MSE managers are reasonably educated, a team of experienced enumerators was participated to collect the data for the sake of a clear understanding of the data collection tool.

The micro and small enterprise growth is the dependent variable of the study. As noted in the literature, MSE growth can be measured in terms of the average annual growth rate of profit and sales. More specifically, in this study, the average annual growth rate was computed as the average profit growth rate between 2015 and 2019. The profit growth rates were computed using the following formula.

$G r_{\text {profit }}=\left[\frac{X_{t}-X_{t-1}}{X_{t-1}}\right] \times 100$

Where: Grprofit $=$ the profit growth rate

$\mathrm{X}=$ the amount of profit that the enterprise make at a specific year $t=$ refers to the time (year)

The data collected through the questionnaire was cleaned, coded, and entered into computer software named SPSS for window version 26. The analysis techniques were performed using a multiple linear regression model.

\section{Result and Discussion}

\subsection{Determinants of Micro and Small Enterprises Growth}

This section outlines the multiple linear regression results to examine the effect of independent variables on the profit growth rate. The necessary diagnostic tests, such as normality, Multicollinearity, and Hetroskedasticity, were checked, and there is no absence of violation. Therefore, all the hypothesized explanatory variables were included in the model, and the coefficients of the variables were estimated. The regression result demonstrates both coefficients of explanatory variables and the corresponding significant values. 
Table 2: Results of Multiple Linear Regression Model

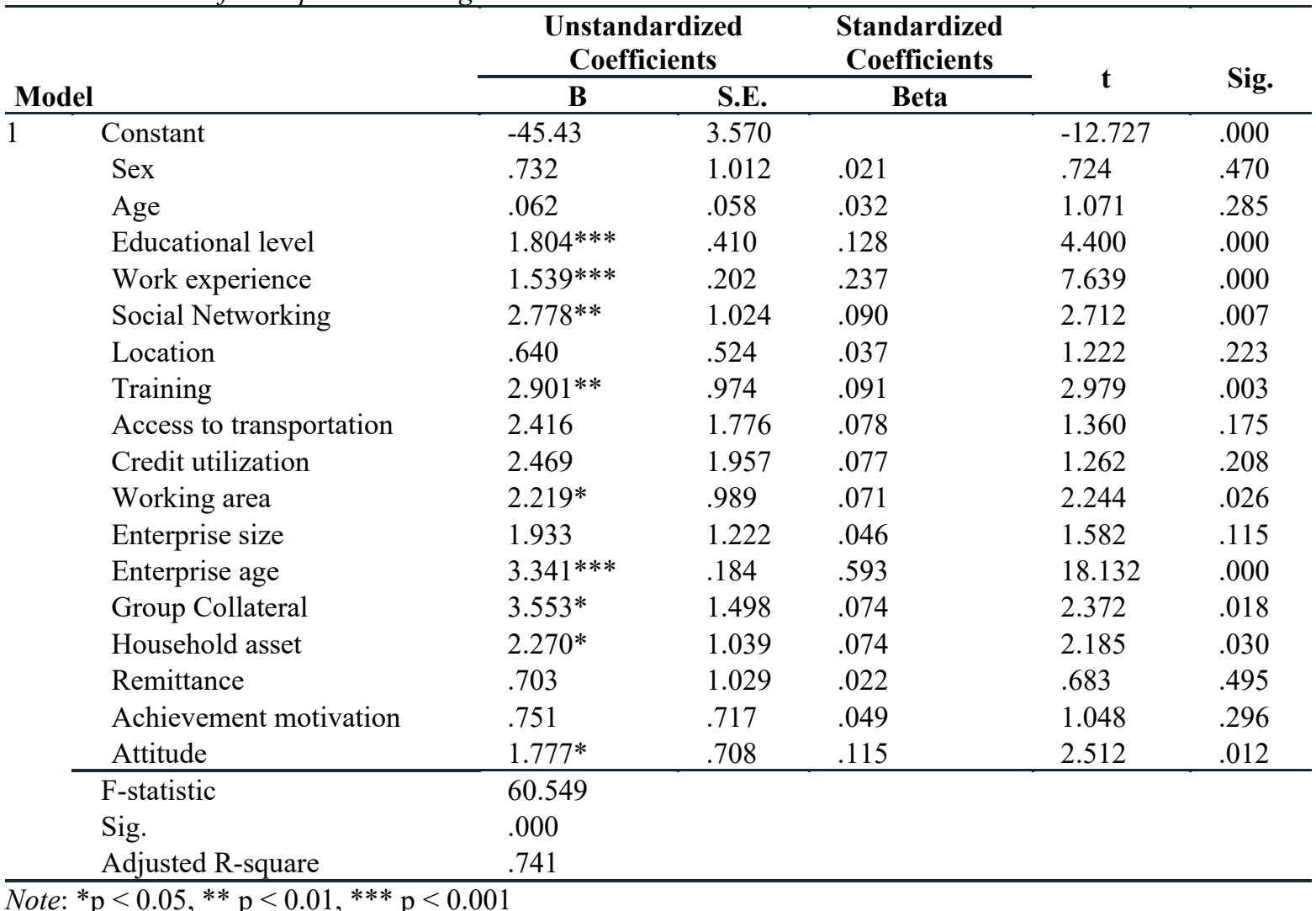

Note: $* \mathrm{p}<0.05, * * \mathrm{p}<0.01, * * * \mathrm{p}<0.001$

The regression results showed that the computed F-statistic (60.5) was significant at one percent. That justifies the suitability of the regression model in determining the profit growth rate. The $\mathrm{R}^{2}$ value of 0.7 implies that about $74.1 \%$ of the variation of profit growth rate has been explained by sex, age, educational level, work experience, social networking, location, training, access to transportation, credit utilization, working area, enterprise size, enterprise age, group collateral, household asset, remittance, achievement motivation, and attitude. The remaining $25.9 \%$ of the variance in profit growth rate was not accounted for by the independent variables considered in the model. According to regression output, out of seventeen (17) variables included in the model, nine (9) predictors have been significant factors that affect the profit growth rate. Therefore, the following paragraphs describe only significant variables with their estimation of the results and their implications.

Educational level: According to the results of Table 4.5, the educational level has a positive and statistically significant effect on the profit growth rate $(\beta=1.8, \mathrm{p}<0.001)$. The regression coefficient results indicate that on average, a one-unit increase of educational level brings 1.8 units to increase in profit growth rate. In line with this, Belay (2012) reported that education positively impacts the entrepreneurs in terms of their marketing ability, business judgment, exposure to new technology, exploiting opportunities resulting in business longevity and growth. The role of education on enterprise growth is explained through its effect on exposure to new information and processing of this new information, which has an ultimately positive impact on enterprise growth rate.

Work experience has a positive and statistically significant effect on the enterprises' profit growth rate $\beta=$ $1.5, \mathrm{p}<0.001)$. The regression coefficient indicates that a one-unit increase of work experience will increase the value of profit growth rate by 1.5 units on average. The result also agreed with Tariku (2018) finding that work experience increases enterprises' production efficiency, and enterprises managed by experienced managers improve the enterprise's growth rate by creating a link between sectors, such as microfinance, TVET, and NGOs. He further argued that when managers have the experience of being able to lead and inspire followers, the enterprises have good production efficiency.

Social networking has a positive and statistically significant effect on profit growth rate $(\beta=2.78, p<0.01)$. The result of the regression coefficient indicates that, on average, those managers who have social networking can have a 2.78 units increase in profit growth rate. This finding is in line with Wolde and Geta (2015) that managers who have social networks have a better chance to improve their micro and small enterprise profit than those who did not have a social network. They further added that social cohesion and mutual support helped firms to be profitable. 
Training has a positive and statistically significant effect on profit growth rate $(\beta=2.9, p<0.01)$. The regression coefficient indicates that, on average, those who have got training will increase the value of profit growth rate by 2.9 units. The findings of Dahling et al. (2013) also confirm that entrepreneurship training was an essential input for enterprise growth. It is familiarized entrepreneurs with the process and organizational function and helped entrepreneurs establish a network with suppliers and buyers. On the other hand, the lack of training institutions adequately equipped for training micro and small enterprises. They also reported that taking training helps enterpreneurs understand and recognize opportunities in every threat to their business growth.

The working area has a positive and statistically significant effect on the profit growth rate $(\beta=2.22, \mathrm{p}<$ 0.1 ). The regression coefficient indicates that on average, those micro and small enterprises that have working area can have a 2.22 units increase in profit growth rate. In connection with this finding, Victor and Boris (2016) noted that access to a suitable workplace is the most critical factor for micro and small enterprises' growth. They also added that access to individual land had been a significant factor in micro and small enterprise growth. Because those enterprises which have no permanent working area being liable for frequent shifting involving high relocation costs to the owners and inconveniences to the customers. As a result, the growth of the enterprise declines from time to time.

Enterprise age has a positive and statistically significant effect on the profit growth rate $(\beta=3.34, p<0.00)$. The regression coefficient indicates that, on average, a one-unit increase of enterprise age will increase the value of profit growth rate by 3.34 units. Supporting this finding, Abraham (2018) indicated that the more extended duration of the business enterprises result in the enterprises' excellent production efficiency. They also added that new enterprises face a significant risk of survival in the business than older ones. Long-period attendance of the enterprises in the business builds enterprises' production efficiency to increase the profit growth rate. Contrary to this finding, Hiebl (2015) argued that older enterprises exhibit lower efficiency since they may suffer greater risk aversion and, therefore, show a lower capacity for innovation, which reduces efficiency.

Group collateral: As specified in Table 4.5, group collateral has a positive and statistically significant effect on profit growth rate $(\beta=3.55, p<0.05)$. The result of the regression coefficient indicates that, on average, those micro and small enterprises that have group collateral can have a 3.55 units increase in profit growth rate. Supporting this finding, Thapa (2015) argued that group collateral is one requirement for establishing micro and small businesses either in cash, capital, or residential house. If members of the group can have collateral, the firm will have much more likely to grow.

The household asset has a positive and statistically significant profit growth rate $(\beta=2.27, \mathrm{p}<0.05)$. The regression coefficient indicates that, on average, those micro and small enterprises that have household assets can have increased the value of profit growth rate by 2.27 units. The finding agrees with Thapa (2015) those household assets' availability increases micro and small enterprise owners' confidence to take a business risk and diversify business units. It wisely happens as business risk analysis is critical and needs tangible household assets on firm growth.

Attitude of the enterprise managers has a positive and statistically significant effect on profit growth rate $(\beta$ $=1.78, \mathrm{p}<0.05)$. The regression coefficient result indicates that those managers who have a positive attitude towards the work they are doing at micro and small enterprises expected a 1.78 units increase in the profit growth rate. The finding is similar to Nkonoki(2010) that personal attitudes can affect micro and small enterprises' profit growth rates. That means entrepreneurs' positive attitude towards the business encourages and becomes a motive for enterprises' growth.

\section{Conclusion}

Work experience and education level of a manager determines the performance of micro and small enterprise growth. Work experience is the most critical factor that increases enterprises' production efficiency. Enterprises managed by experienced managers improve their growth rate since experienced managers can lead and inspire followers to facilitate good production efficiency and improve their enterprise profitability. Equally, the educational level positively impacts the entrepreneurs in terms of their marketing ability, business judgment, exposure to new technology, exploiting opportunities resulting in business longevity, and growth. More educated enterprise managers have better exposure to new information and ability to process this new information, which has an ultimately positive impact on enterprise growth rate.

On the other hand, micro and small enterprises with no group collateral and have shorter duration become less profitable and accumulate low capital. New enterprises entering the market are unaware of their real efficiency immediately since they have gathered less information than older ones. They can uncover their production costs and boost their capital growth rate as they mature. Therefore, new enterprises face a significant risk of survival in the business than older ones. Likewise, the absence of group collateral is another factor for the firm to grow. Formal financial institutions cannot meet micro-enterprises' needs unless the enterprises have no collateral. Financial institutions prefer large firms to give huge loans at a high-interest rate, which becomes difficult for micro and small enterprises with no collateral to be profitable and grow as expected. 


\section{REFERENCE}

Abraham Ababiya. (2018). Financial Performance of Agricultural Enterprises and Their Determinant Factors in Hadiya Zone, Ethiopia. European Journal of Business and Management, 10(19), 25-34

Audretsch, D.B. and Klepper, S. (2000). Innovation, Evolution of Industry and Economic Growth", Elgar Reference Collection. International Library of Critical Writings in Economics, Cheltenham, U.K. and Northampton, Mass.

Belay, G. (2012). Determinants of Microenterprises Success in Urban Informal Sector of Addis Ababa: Multidimensional Analysis. Thesis to obtain the degree of Doctro from th Erasmus University Rottered. Netherlands.

Dahling, J. J., Melloy, R., \& Thompson, M. N. (2013). Financial strain and regional unemployment as barriers to job search self-efficacy: A test of social cognitive career theory. Journal of Counseling Psychology, 60 (2), 210-218.

Hiebl, M.R. (2015). Family involvement and organizational ambidexterity in later generation family businesses: A framework for further investigation. Journal of Management Decision, 53(5): 1061-1082.

Kamau, J.M. and John, K.N. (2014). Factors Affecting the Growth of Small and Micro Enterprises Dairy Farmers' in Kenya: Case of Gatundu South Farmer's Dairy Co-Operative Society Ltd, Kenya. International Journal of Current Business and SocialSciences, 1, 48-63.

Kausar, A. (2013). Factors effect microcredit's demand in Pakistan. International Journal of Academic Research in Accounting, Finance and Management Sciences, 3 (4), 11-17.

King, K. \& McGrath S. (2002). Globalization, Enterprise and Knowledge: Educational Training and Development, International Review of Education, Vol. 50(1), 74-76(3)

Leza, T., Rajan, S., \& Kuma, B. (2016). Determinants of employment growth of micro and small enterprises in Wolaita Zone, Ethiopia. International Journal of Current

MOTI. (2005). Micro and Small Enterprises Development Strategy. Addis Ababa: the Federal Democratic Republic of Ethiopian Ministry of Trade and Industry.

Nganda, J. W., Wanyonyi, K. W., \& Kitili, E. M. (2014). Determinants of growth of small and medium enterprises in Kakamega central sub-county, Kenya. Journal of Business Administration and Management Sciences Research, 3(3), 022-031.

Nkonoki, E. (2010). what are the factors limiting the success and growth of small businesses in Tanzania. An empirical study on small business growth.

Oppong, M., Owiredu, A., \& Churchill, R. Q. (2014). Micro and small scale enterprises development in Ghana. European Journal of Accounting Auditing and Finance Research, 2(6), 84-97.

Taciana, M.A.,Marcio, T.L., Felipe, S.F., Luiz, C.O. (2017). Technical efficiency in dairy farms: Research framework, literature classification and research agenda. International Journal of Productivity and Performance Management, 66(3): 1-42.

Tariku, Ayele. (2018). Review of factors affecting the performance of micro and small enterprise in Ethiopia. International Journal of Political Science and Development, 6(8): 275-279.

Tekle Leza, Rajan, S., \& Berhanu Kuma.(2017). Determinants of Employment Growth of Micro and Small Enterprises in Wolaita Determinants of Employment Growth of Micro and Small Enterprises in Wolaita. International Journal of Current Research, 8(12), 43177-43186.

Tekle, Leza, Sandraa, R., Berhanu, Kuma. (2016). The determinant of technical efficiencies of micro and small enterprises in Wolaita Zone, Ethiopia. Journal of Economics and Sustainable Development, 7(21): 22222855

Thapa, A. (2015). Determinants of microenterprise performance in Nepal. Small Business Economics, 45(3), 581-594

Victor, H.M. \& Boris. E.B. (2016). Total factor productivity change in dairy farming: Empirical evidence from southern Chile. Journal of Dairy Science, 99: 1-9.

Victoria, M., Samuel, B., Lloyd, C., \& Lazarus, M. (2011). Determinants of small and medium enterprises failure in Zimbabwe: a case study of Bindura. 2(5), 82-89.

Wolde, F., \& Geta, E. (2015). Determinants of growth and diversification of micro and small enterprises: the case of Dire Dawa, Ethiopia. Developing Country Studies, 5(1), 61-75.

Yitbarek Abrha Asfaw. (2016). Growth determinants of manufacturing micro and small enterprises in Ethiopia: An empirical study of Tigray Province. Enterprise Development and Microfinance, 27(4), 273-297. 